\title{
Jasmin Hodžić
}

Research Associate at the Language Institute, University of Sarajevo

Primary Interests: Syntax, Sociolinguistics, Accentology, Cognitive Linguistics

Language Institute, University of Sarajevo

Bosnia and Herzegovina

jasmin.hodzic@izj.unsa.ba

\section{STEPEN AMBIGVITETNOSTI SINTAKSIČKI HOMONIMNIH STRUKTURA U BOSANSKOM JEZIKU}

\section{Uvod}

Dvije sintaksički homonimne strukture proizlaze iz preklapanja njihove sintaksičke interpretacije čime tako dvije homonimne postaju jedna sintaksički ambigvitetna (sintaksički dvosmislena) konstrukcija. ${ }^{1}$ Zato se, u najprostijem kazano, o homonimnosti i dvostrukom značenju jedne sintaksičke strukture može reći sljedeće: Dvosmislene su rečenice one koje imaju isti plan izraza ili površinsku strukturu, a dva značenja [Hadžiefendić-Parić 2003: 23]. Ili: Dvosmislenost na nivou rečenice nastaje kada se pogrešno protumače sintaksičke funkcije $u$ rečenici [Prodanović-Stankić 2013: 80]. Pogrešnim, odnosno, različitim tumačenjem sintaksičkih funkcija članova jedne rečenice od iste takve rečenice dobijamo novu, po značenju sasvim drukčiju rečenicu. Ovim će ta jedna rečenična struktura postati potpuno sintaksički homonimna drugoj.

Posebno je važno sagledati da li će po prirodi gramatičke strukture jednog jezika jedan gramatički sistem proizvesti niz potencijalno dvosmislenih sintaksičkih konstrukcija i kakav je odnos između potencijalne i stvarne sintaksičke dvosmislenosti (homonimije), odnosno, kakav je stepen ambigvitetnosti jedne takve homonimne konstrukcije.

Iako se često za prisustvo dvosmislenosti u jezičkoj strukturi navodi to da se ona uglavnom razrješava kontekstom, kroz različite vidove upotrebe jezika i kroz primjere iz različitih funkcionalnih stilova standardnog jezika može se uočiti da su

${ }^{1}$ Preklapanje sintaksičkih interpretacija odnosi se ustvari na istovjetnost sintaksičkih formi koje se mogu interpretirati na isti način. 
gramatički (sintaksički) dvosmislene konstrukcije u bosanskom jeziku postojane i prisutne, pri čemu se izdvaja kategorija ciljanog, tj. namjernog (poželjnog) ambigviteta i kategorija nenamjernog (nepoželjnog) prisustva sintaksičkog ambigviteta u jezičkoj strukturi. Dakle, u nekim tipovima tekstova sintaksički ambigvitet je ciljano prisutan (npr. u korpusu humorističkih tekstova), dok su u drugim tipovima tekstova gramatički dvosmislene konstrukcije također prisutne, a ne bi ih smjelo biti (npr. u administrativno-pravnom stilu savremenog jezika). Posebno je važno i to da bosanske (hrvatske, srpske, srpskohrvatske) gramatike također kategoriji sintaksičke dvosmislenosti posvećuju određenu pažnju, s tim da bi opisi sintaksičke dvosmislenosti u našim gramatikama trebali biti potpuniji. O samom karakteru dvosmislenosti svake pojedinačne dvosmislene konstrukcije može se precizno govoriti kroz određivanje stepena ambigvitetnosti kao mjerljive kategorije koja dodatno opisuje prirodu dvosmislene konstrukcije i u pojedinačnom i u općem smislu.

\section{Tipovi sintaksički homonimnih konstrukcija}

Kod opisa vrsta sintaksički dvosmislenih/homonimnih struktura u bosanskom jeziku možemo govoriti o strukturalnom, referencijalnom te o determinativnom tipu ambigviteta, s jedne strane (gdje se dvostruka sintaksička interpretacija izvodi iz različitih kombinatornih varijanti jedne jezičke strukture, uz izvođenje i primjenu različitih referencijskih i determinacijskih odnosa; i ovaj tip sintaksičke dvosmislenosti čest je kod primjera upotrebe zamjenica, brojeva, veznika, pridjeva i priloga, ali i kod specifičnih padežnih konstrukcija; up. a) Nove kuće i prodavnice; b) Dio sobe površine $7 \mathrm{~m}^{2}$; c) Svima je dosta jedna marka); a zatim i o transformacionom tipu dvosmislene strukture (gdje je osim grupisanja rečeničnih elemenata važan faktor i izvođenje dodatnih trasnsformacija, npr. transofmisanje prijedložno-padežnog izraza iz priloške u atributsku funkciju; up. Dočekali su čovjeka sa smiješkom; ali opet i kod specifičnih padežnih značenja, up. Hapšenje policajaca bilo je zabrinjavajuće). Up. [Hodžić 2016].

Drugo ime za sintaksički ambigvitet jeste sintaksička homonimija. Inače, sintaksička homonimija je mnogo manje uočljiva od leksičke a kod samih primjera sintaksičke homonimije može se raditi o različitim nivoima (stepenima) homonimnosti jedne takve strukture, pa je i to jedan od razloga zašto je za prepoznavanje sintaksički homonimnih konstrukcija potrebno ulagati dodatne napore. Inače: Pod sintaktičkom homonimijom (nejednoznačnošću) fraze podrazumijeva se mogućnost da se frazi pripiše više nego jedna pravilna sintaktička struktura [Jordanskaja 1967]. Dakle, u dekodiranju i uočavanju homonimnih struktura nije presudan samo površinski značenjski sloj već i dubinsko jezičko (primarno sintaksičko) (pred)znanje. Zato je bitno i sljedeće: U načelu, kazat ćemo da imamo slučaj konstrukcione homonimije, onda kada se određen niz fonema na nekom nivou može analizirati na više od jednog načina [Čomski 1984: 102]. Također, u Palić [1999] navodi se primjer ,dvostruke sintaksičke zavisnosti“ koji se može dovesti u vezu sa „homonimičnom strukturom“ koja „zahtijeva dvije sintaksičke interpretacije“, 
tj. takva je rečenica u kojoj su „dva različita semantička sadržaja predstavljena istom sintaksičkom strukturom [v. Palić 1999]. Iako se na prvi pogled o sintaksičkoj dvosmislenosti može govoriti i kao o polisemiji, kako vidimo, riječ je zapravo o homonimiji na sintaksičkom nivou.

\section{Sintaksička dvosmislenost i kontekst}

Važno je istaći da to što u kontekstu nekada možemo razabrati šta bi određena konstrukcija trebala da znači, da ustvari pritom nismo sigurni da ona svojom strukturom to zaista i znači, tj. to ne znači da je ista ta konstrukcija i (sintaksički) ispravna. Na primjer, Radovanović [2003: 274] za rečenicu kojoj pragmatičkim parametrima oduzima stvarnu dvosmislenost kaže i to da je takva rečenica ,jedan očigledno pogrešno obrazovan rečenični kompleks" [Radovanović 2003: 274] navodeći rečenicu: Samo je udario loptu g l a vo $m$ k oj a se otkotrljala u aut - uz komentar da će se uslijed pragmatičkog konteksta ova rečenica uvijek ispravno shvatiti. Međutim, veoma je ovdje bitna konstatacija da je rečenica ustvari pogreš$n a, \mathrm{tj}$. pogrešno obrazovana. Također, Radovanović [1990] navodi i slučajeve postojane dvosmislenosti u ,veštački stvorenoj izolaciji iz konteksta“.

Ovdje o odnosu potencijalne i stvarne dvosmislenosti možemo dati nekoliko osnovnih tvrdnji:

- Poznato je da se značenja svih naših riječi u konačnici dobijaju u kontekstu (up. glava - glava kuće, glava motora, glava lutke).

- Pitanje je koliko se kontekst u pojedinim izrazima zapravo može odrediti, tj. upravo će prisustvo potencijalne sintaksičke dvosmislenosti uzrokovati pometnju u određivanju konteksta.

- Gramatika se primarno bavi strukturom, odnosno formom, a ne kontekstom, tj. sintaksa primarno proučava pravila slaganja riječi i formalnu stranu rečenice, a ne njena značenja, iako sama rečenična struktura utječe na značenje.

- Ako već govorimo o prisustvu i poništavanju dvosmislenih konstrukcija, trebalo bi ukazati na moguće načine poništavanja dvosmislenosti na nivou sintaksičke strukture, dakle na nivou gramatike, a ne da se ona razrješava kontekstom.

- Tvrdnja da se značenje dvosmislenog iskaza pronalazi tek u kontekstu i tako razrješava dvosmislenost sama za sebe ustvari govori kako svojom strukturom data rečenica ima dva smisla, i da se (bez konteksta) ne može odrediti koji je ciljani smisao rečenice - dakle, dvosmislenost takve strukture je postojana.

Uputno je ovdje istaći zapažanje M. Mihaljevića [1998]: Bilo kakav niz leksičkih jedinica nekoga jezika može biti interpretiran ako postoji dovoljno bogat kontekst. To ne znači da je svaki takav niz i pravilno sastavljen [Mihaljević 1998: 115].

Dakle, niz leksičkih jedinica, odnosno sintaksička struktura iskaza ne bi smjela da bude „bilo kakva“ i pri tom se ne bi smjeli rukovoditi kontekstom ili mogućnošću interpretacije, i da nam ta dva faktora budu dovoljna. Ne možemo se zadovoljiti samo uslovima ispravne interpretacije u kontekstu (što, naravno opet, nije uvijek ni moguće), već moramo uzeti u obzir da osim ovog dovoljnog uslova 
trebamo prihvatiti i potreban uslov: Iskaz bi morao biti i sintaksički i semantički jasan i precizan. Dakle, tačno je da se dvosmislenost uglavnom razrješava u kontekstu i preko niza pragmatičkih parametara, ali ne uvijek. Također, i onda kada možemo rečenicu protumačiti u kontekstu, ona nam strukturno može biti nepravilna, u šta spada i primjer dvosmislene rečenice. Tako: Iako nam riječi mogu biti potpuno „pravilne“, naša rečenica može ispasti naopaka ako nismo vješti da riječi iznitimo u jezičku nit koja će biti sintaksički ispravna i sadržajno suvisla [Riđanović 1979]. Sintaksički ambigvitet je ustvari tako i pitanje normatvne sintakse i jasnog i pravilnog stila izražavanja [up. Hodžić 2015]. Dvosmislenost strukturnog tipa treba i rješavati u strukturi, a ne u kontekstu.

\section{Sintaksička dvosmislenost u procjeni izvornih govornika - anketiranje}

Preko internetskog servisa „google obrasci“ (engl. google forms, odnosno, internetske stranice: https://www.google.com/intl/bs/forms/about/) moguće je izraditi anketu kojom će se od ispitanika (izvornih govornika) tražiti da opišu karakter ponuđenih potencijalno sintaksički dvosmislenih rečenica. Od ispitanika se konkretno može tražiti da zaokruže/obilježe koje ponuđeno značenje ima data rečenica. No, ovdje ima jedna zanimljiva specifičnost. Naime, tehnički je moguće da svi ispitanici zaokruže i samo jedan od primjera ponuđenih odgovora, odnosno da niko od ispitanika ni za jednu rečenicu ne kaže da je dvosmislena, a da rezultat anketiranja pokazuje suprotno, tj. da zaključimo kako su ponuđene rečenice ipak dvosmislene. U protivnom, odlučili bismo se za zaključak da ponuđene rečenice nisu dvosmislene, ali to bi bilo samo u slučaju da se svi ispitanici odluče za tačno ista/poduradna rješenja (npr. da svi tvrde da neka rečenica br. 5. ima značenje 1. a rečenica br. 6. ima značenje 2., i slično tome). Međutim, pojedinačno gledano, može se desiti da niko od ispitanika ne tvrdi da su ponuđene rečenice dvosmislene, a da nas krajnji rezultat i zaključak, kako smo već rekli, navodi na suprotno. Tako anketa može pokazati da su sve rečenice dvosmislene i onda kada se svi ispitanici odluče za samo jedno od ponuđenih značenja. To je u slučaju kada nekom od ispitanika jedna rečenica ima jedno, a nekom ista ta rečenica drugo ponuđeno značenje (iako su se oba ispitanika odlučili samo za jedno značenje). Štaviše, ovakvo nešto će predstaviti ovjereniji rezultat o prirodi ambigvitetnosti s obzirom na to da u tom slučaju kao da smo pretpostavili da rečenice zapravo nisu dvosmislene i pritom tražili od ispitanika da se odluče samo za jedno od značenja, pri čemu bi rezultati ipak mogli pokazati da sve rečenice imaju dva značenja. Ipak, obuhvatnije anketiranje će biti onda kada se od ispitanika ne traži da se odrede između dva značenja, odnosno kada se ne traži da odabirom jednog eliminiraju drugo značenje. Potpunije ispitivanje, dakle, bit će onda kada se ispitanicima da mogućnost da „glasaju“ za sva ponuđena značenja, tj. da svojim odabirom mogu zaokružiti više (ponuđenih) značenja i još eventualno upisati i svoje, treće značenje, kada je ono moguće. 


\subsection{Stabilnost i ujednačenost značenja dvosmislenih rečenica}

Shodno rezultatima našeg istraživanja [v. Hodžić 2016] sačinili smo listu reprezentativnih primjera dvosmislenih sintaksičkih struktura u bosanskom jeziku, koju smo u obliku ankete ponudili izvornim govoricima na procjenu značenja. ${ }^{2}$ Cilj je bio sagledati kako će izvorni govornici poimati značenje ponuđenih primjera i hoće li ponuđeni primjeri procjenom informanata također pokazati karakter dvosmislenosti. Pri svemu tome se moglo sagledati kakav je odnos ponuđenih značenja dvosmislenih rečenica, odnosno može se tačno ispitati kakav je omjer ponuđenih značenja i u kojoj mjeri su takva značenja ujednačena. Nekada će tako dva ponuđena značenja potpuno ravnopravno odgovarati ispitivanoj rečenici, a nekada će jedno značenje biti dominantno, a drugo samo vjerovatno. U slučaju kada imamo izrazito dominantno jedno značenje, može se ispitati kakva je njegova stabilnost, tj. u kojoj mjeri je ono dominantno u percepciji izvornih govornika. Time ispitujemo odnos primarnog značenja prema samoj ispitivanoj rečenici, tj. koliko ostaje vjerovatnoće i za uvođenje drugog značenja. Iz procenta svih pridruženih odgovora/glasova koje dominantno značenje uzima za sebe možemo izraziti sam stepen ambigvitetnosti. Na primjer, ako dominantno značenje zauzima $70 \%$ svih odgovora $u$ anketi, sam stepen ambigvitetnosti takve rečenice iznostit će 30\%. Stepen ambigvitetnosti je dakle obrnuto proporcionalan stabilnosti (glavnog) značenja. Ukoliko je stepen ambigvitetnosti 50\%, tada će postojati jednaka vjerovatnoća za dva ponuđena značenja i takva rečenica neće imati dominantno značenje jer dva ponuđena značenja imaju 50\% vjerovatnoće (dakle, potpuno ravnopravne šanse) da odgovaraju traženom značenju. No, dvije različite rečenice mogu imati stepen ambigvitetnsti 30\% (njihovo dominantno značenje zauzima $70 \%$ odgovora $u$ anketi) a da im se broj odgovora pridruženih manje vjerovatnom značenju razlikuje. Jer, kako postoji mogućnost za odabir oba značenja, neće biti slučaj da manje vjerovatno značenje zauzima ostatak procenata od dominantnog (spomenutih 70 prema 30), već manje vjerovatnom značenju jedne rečenice može pripadati bilo koji broj procenata, samo da je manji od dominantnog. Time dvije rečečenice sa istim stepenom ambigvitetnsoti mogu imati različit međusobni omjer mogućih značenja (jedno manje vjerovatno značenje može biti vjerovatnije od drugog manje vjerovatnog). Takav omjer rezultat je ispitivanja

${ }^{2}$ Ispitivane rečenice su u obliku priloga uvrštene u studiju [Hodžić 2016] - Hodžić, Jasmin, Tipovi sintaksičkog ambigviteta u bosanskom jeziku, Doktorska disertacija u rukopisu; Fakultet humanističkih nauka Univerziteta „Džemal Bijedićc u Mostaru. Također, uvid u kompletan ispitivani meterijal moguće je izvršiti na internetskoj adresi: https://goo.gl/forms/Rs2mpxzhxUuSG3u13. Ovdje izdvajam i neke od ispitivanih rečenica uvrštenih u spomenutu formu ankete: Zlo će u konačnici nadvladati dobro, Veležu je nemoguće uzeti naslov, Donio sam mandarine iz Opuzena, Dočekali su čovjeka sa smiješkom, On ti je kupio dvoje cipele, Više trgovina ljudima nije zanimljiva, Poljubi mi malog dolje, Alen i Alma ili Amir će doći na sijelo, Nije Alma pisala poruku Damiru, Onaj čovjek se osuđuje na smrt, Treba nam višse humanijih oficira, Hapšenje policajaca bilo je zabrinjavajuće, Trebala je duže suknje nositi, Ja ću joj uzeti čarape, Čovjeka koji je ubio djeda, lovokradicu, doveli su na sud, Na večeru će doći komšije koje smo jutros pozvali, Obećao joj je da će konačno saznati sve o njemu, Ja sam mislila da možda nećeš sutra ići itd. 
ujednačenosti mogućih značenja i nazvat ćemo ga indeks stepena ambigvitetnosti. ${ }^{3}$ Dakle, iz stabilnosti (dominantnog, primarnog) značenja izračunavamo stepen ambigvitetnosti, a kod proračunavanja ujednačenosti manje vjerovatnog i dominantnog značenja može se izraziti indeks stepena ambigvitetnosti.

\subsubsection{Stepen ambigvitetnosti $i$ indeks stepena ambigvitetnosti}

Naveli smo već da se može precizno ispitati kakav je međusobni odnos mogućih značenja, odnosno koliko je jedno značenje u prednosti nad drugim, a ponegdje i trećim značenjem kod sintaksički dvosmislenih rečenica. Ovaj omjer nazvali smo indeks stepena ambigvitetnosti. Međutim, sam stepen ambigvitetnosti datih rečenica za razliku od indeksa stepena ambigvitetnosti sagledat ćemo na drugi način. Prije svega, kako smo i naveli, kroz ispitivanje indeksa stepena ambigvitetnosti ispitujemo ujednačenost (mogućih) značenja. No, kroz analizu ujednačenosti dva moguća značenja (vjerovatnog i dominantnog) možemo ispitati i to koliko je dominantno značenje postojano, tj. koliko će rečenica imati predispoziciju da izgubi na svom značenju, odnosno kolika je šansa da jedna rečenica zadrži dominantno značenje. Ustvari, pritom ispitujemo kakav je odnos dominantnog značenja prema zadanoj rečenici koja se tumači (koliki procenat odgovora otpada na vjerovatnije značenje) i tako zapravo ispitujemo kolika je opravdanost po pretpostavci jedno značnje gledati kao dominantnije od drugog (tj. kakva je dominanta značenja u procentima). Iz procenta koji dominantno značenje uzima za sebe možemo izaziti sam stepen ambigvitetnosti. Stepen ambigvitetnosti je dakle obrnuto proporcionalan stabilnosti (glavnog) značenja. Isto tako, indeks stepena ambigvitetnosti direktno je proporcijalan ujednačenosti značenja. Još jednom, kroz analizu ujednačenosti sagledavamo koliku prednost jedno značenje ima nad drugim (dakle, kakva je ujednačenost mogućih značenja), a kroz analizu stabilnosti značenja provjeravamo u kojoj mjeri data rečenica zadržava dominantnije značenje.

Đorđević [1979] prenosi istraživanje do kojih su došli MacKay i Bever [1967] koji dvosmislene rečenice kod kojih moguća značenja nisu ravnopravna nazivaju nefunkcionalnim dvosmislenostima, a rečenice „kod kojih jedno od značenja u psihološkoj realnosti nema prednost nad drugim značenjem, odnosno, značenjima“, tj. kod kojih su moguća značenja ravnomjerna nazivaju se funkcionalnim dvosmislenostima.

Također, Đorđević [1979] razlikuje tri stepena dvosmislenih strutura: a) dvosmislene rečenice sa visokim stepenom dvosmislenosti (ili „funkcionalne dvosmislenosti“"), b) rečenice sa niskim stepenom dvosmislenosti (ili „nefunkcionalne dvosmislenosti“") i c) rečenice sa srednjim stepenom dvosmislenosti.

${ }^{3}$ Nije nebitno koliko je ustvari vjerovatno to manje vjerovatno značenje o kojem govorimo. Ono npr. može biti jako blisko dominantnom, tj. da se recimo za dominantno značenje odluči $90 \%$ ispitanika, a da manje vjerovatno značenje dobije $80 \%$,glasova“. Ovaj podatak zapravo pokazuje da ni manje vjerovatno značenje u ovom slučaju nije „nebitno“. 
Nama su ovdje posebno interesantne rečenice sa srednjim stepenom dvosmislenosti, odnosno, one rečenice kod kojh se stepen dvosmislenosti kreće od srednjeg ka višem, jer su i takve rečenice po svemu također funkcionalno dvosmislene.

Sam stepen dvosmislenosti Đorđević [1979] poima na sljedeći način: Stepen dvosmislenosti kao odrediva kategorija stoji u obrnutoj proporciji sa razlikom između primarne i sekundarne interpretacije [Đorđević 1979: 538].

U našem poimanju na ovaj način govorili smo o indeksu stepena ambigvitetnosti (nešto preciznija vrijednost od opće kategorije ambigvitetnosti) kao međusobnom omjeru vjerovatnog i dominantnog značenja, dok smo na stepen ambigvitetnosti gledali kao na suprotnu vrijednost stabilnosti glavnog značenja.

Međutim, Đorđević [1979] dolazi do zaključka da „dvosmislenost ne predstavlja veliku prepreku u komunikaciji“ uz tvrdnju da (se) „funkcionalnost se kreće od srednjeg prema nižem stepenu dvosmislenosti““ [Đorđević 1979: 538].

Naše istraživanje pak pokazuje da $60 \%$ ispitanih primjera pokazuje sredjni i viši stepen funckionalne vrijednosti dvosmislene strukture.

Dodatno, rezultati do kojih smo doši pregledno pokazuju ujednačenost mogućih značenja dvosmislenih rečenica u bosanskom jeziku, te samu stabilnost dominantnog značenja. Naše istraživanje je izvšeno na korpusu od šezdeset reprezentativnih dvosmislenih rečeničnih struktura.

Grafik 1. Stabilnost značenja

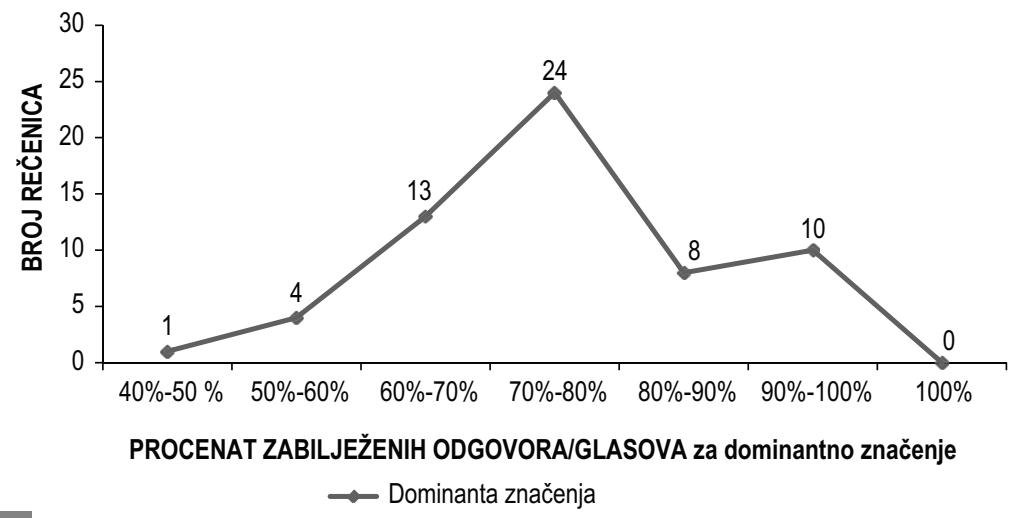

Źródło: Izvor: [Hodžić 2016].

Grafik dominante značenja na horizontalnoj osi sadrži podatke o tome koliko posto je od ukupnog broja mogućih odgovora/glasova pridruženo dominantnom značenju, a na vertikalnoj osi podatke o broju rečenica na koje se ti odgovori odnose.

Kako pokazuje grafik, niti jednom značenju niti jedne rečenice nije pridruženo $100 \%$ odgovora/glasova, što je zapravo drugi način da se utvrdi kako su sve rečenice dvosmislene. 
Također, najveći je broj rečenica, ukupno 24 (oko 39,34\%), koje su za sebe vezale između $70 \%$ i $80 \%$ svih mogućih odgovora/glasova za svoje dominantno značenje, pa bi srednja vrijednost stpena ambigvitetnosti ovdje iznosila $25 \%$, i time će od ukupnog broja ponuđenih primjera u provedenoj anketi oko $40 \%$ ispitivanih rečenica imati srednju stabilnost dominantnog (glavnog, primarnog) značenja, dok nešto veću stabilnost značenja pokazuje ukupno 8 rečenica (oko $13 \%$ ). Ipak, najveću stabilnost (dominantnog) značenja pokazuje svega 10 rečenica $(16,40 \%$ od svih ispitivanih primjera), čiji je stepen ambigvitetnosti najmanji, i po srednjoj vrijednosti iznosi svega 5\%. Zaključno, oko $70 \%$ ispitivanih rečenica pokazuje dosta veliku stabilnost dominantnog značenja (od srednjeg ka najvišem nivou).

Ovdje je pak od presudne važnosti uvesti kategoriju indeksa stepena ambigvitetnosti, gdje prelazimo na rezultate analize odnosa mogućih značenja svih rečenica u anketi, kroz odnos manje vjerovatnog prema dominantnom značenju.

Grafik 2. Ujednačenost značenja

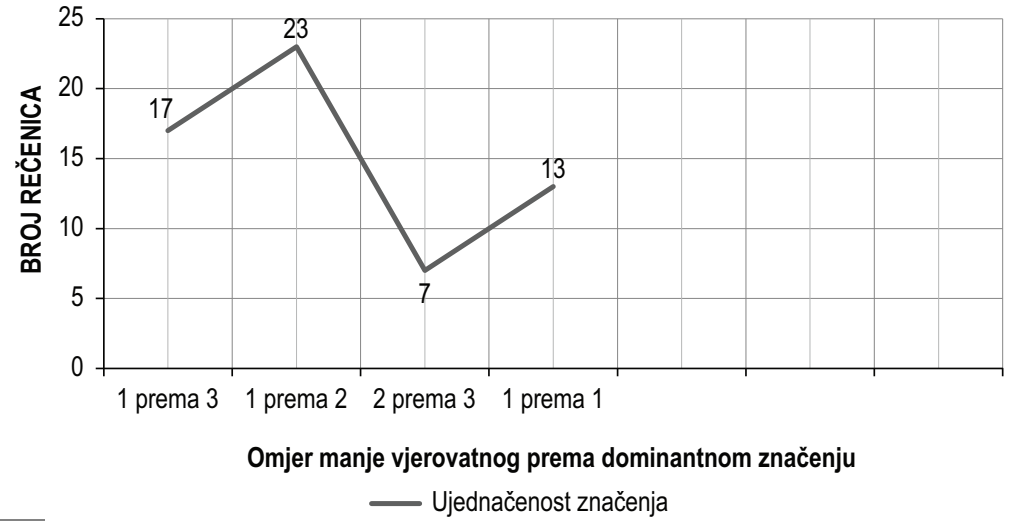

Do autora: Izvor: [Hodžić 2016].

Horizontalna osa ovog grafika sadrži oznake omjera tzv. manje vjerovatnog prema dominantnijem značenju primjera dvosmislene rečenice, a vertikalna osa ukupan broj rečenica koje pripadaju datom omjeru.

Rezultati analize pokazuju da potpuno ujednačeno značenje (potpuno iste šanse za moguća dva značenja) ima ukupno 13 rečenica $(21,31 \%)$, odnosno približno jednu petinu od ukupog broja analiziranih rečenica. Samim tim, ove rečenice nemaju dominantnog značenja. Njihov indeks stpena ambigvitetnosti iznosi 1. Ovo su tzv. tipični primjeri funkcionalne dvosmislenosti. Najviše rečenica, ukupno 23 (37, 70\%), otpada na one primjere u kojima je vjerovatno spram dominantnog značenja približno dva puta manje, pa je njihov indeks stepena ambigvitetnosti $1 / 2$. Nešto veću ujednačenost mogućih značenja (vjerovatnog i dominantnog), kod idneksa stepena ambigvitetnsoti $2 / 3$, pokazuje ukupno 7 rečenica $(11,47 \%)$ dok će najveću razliku između vjerovatnog i dominantnog značenja (kod indeksa stpeena ambigvitetnosti $1 / 3)$ pokazati ukupno 17 rečenica $(27,87 \%)$, što je prib- 
ližno jedna trećina analiziranih primjera. Iz analize stepena ambigvitetnosti je izuzeta jedna rečenica, zbog prevelike razlike između dominantnog i vjerovatnog značenja.

Kroz ispitivanje indeksa stepena ambigvitetnosti pokazuje se da oko $30 \%$ rečenica ima tipičnu funkcionalnu dvosmislenost, tj. veliku ujednačenost između primarnog i sekundarnog značenja dvosmislene sintaksičke konstrukcije, dok na dodatnih $30 \%$ otpada srednja vrijednost ove funkcionalne dvosmislenosti, odnosno, ujednačenosti mogućih značenja.

\section{Zaključak}

U radu smo pregledno pokazali o kakvim se dvosmislenim strukturama može govoriti kod sintaksički homonimnih konstrukcija u bosanskom jeziku (strukturalni, referencijani, determinativni i transformacioi tip dvosmislene konstrukcije), da bismo problematizirali sami odnos potencijalnog i stvarnog sintaksičkog ambigviteta iskazan kroz opisivanje uloge konteksta u dekodiranju dvosmislene sintaksičke konstrukcije. O karakteru dvosmislene sintaksičke strukture govorili smo kroz odredivu kategoriju stepena dvosmislenosti, tj. kroz opisivanje stabilnost $i$ primarnog značenja (koja je obrnuto proporcionalna stepenu ambigvitetnosti) a zatim i kroz odnos mogućih značenja jedne dvosmislene konstrukcije (koji se izražava indeksom stepena ambigvitetnosti). Vidljivo je da oko $70 \%$ ispitivanih rečenica pokazuje srednju i nešto veću stabilnost dominantnog (primarnog) značenja. Također, kod $60 \%$ rečenica ispitanih našom anketom prisutna je nešto veća ujednačenost između primarnog i sekundarnog značenja kao mogućih značenja jedne sintaksički homonimne strukture. Ispitivanje ovih parametara koji se vežu za stepen ambigvitetnosti sintaksički homonimne strukture direktan je put do shvatanja njenog karaktera dvosmislenosti - saznajemo koliko je takva dvosmislenost postojana, koliko je stvarna i kakav je odnos više mogućih značenja jedne takve dvosmislene (tj. homonimne) rečenične strukture.

\section{Bibliografija}

Čomski N. (1984), Sintaksičke strukture, Novi Sad.

Đorđević R. (1979), Tumačenje sintaksičke dvosmislenosti u engleskom jeziku, Beograd.

Hažiefendić-Parić R. (2003), Naš jezik, IV razred, Sarajevo.

Hodžić J. (2015), Sintaksa kao dio pravopisa - pravopisna sintaksa, [u:] Educa, Časopis za obrazovanje, nauku i kulturu, br. 8, Mostar.

Hodžić J. (2016), Tipovi sintaksičkog ambigviteta u bosanskom jeziku, doktorska disertacija u rukopisu, Mostar.

Jordanskaja L. (1967), Syntactical ambiguity in Russian (with respect to automatic analysis and synthesis), [u:] Scientific and Technical Information, Moscow.

MacKay D. G., Bever T. G. (1967), In Search of Ambiguity, [u:] Perception and Psychophysics, 2: 193-200.

Mihaljević M. (1998), Generativna sintaksa i semantika, Zagreb.

Palić I. (1999), O jednom primjeru sintaksičke zavisnosti, [u:] Časopis Bosanski jezik, s. 103 -110, Tuzla. 
Prodanović-Stankić D. (2013), Jezički i vanjezički aspekti verbalnog humora u engleskom i srpskom jeziku na primeru filmskihi i televizijskih dijaloga: kognitivnolingvističk pristup. Doktorska disertacija, Novi Sad.

Radovanović M. (1990), Spisi iz sintakse i semantike, Sremski Karlovci - Novi Sad.

Riđanović M. S (1979), O jednom zanemarenom vidu pismenosti, [u:] Naš jezik u praksi, Priručnici 2, Sarajevo.

\title{
Jasmin Hodžić
}

\section{THE DEGREE OF AMBIGUITY OF HOMONYMOUS SYNTACTIC STRUCTURES IN THE BOSNIAN LANGUAGE}

\begin{abstract}
(Summary)
In this paper has been specifically considered the issue of the potential and the actual syntactic ambiguity (or syntactic homonymy) which has led to the results indicating that the existence of ambiguity in syntax is not negligible, and that the role of the context in the analysis of the syntactic ambiguity is not as it has been assumed. A selected number of examples have been presented to native speakers in order to assess the meaning. The results of this questionnaire show that the native speakers have confirmed the ambiguity of all the sentences. Ambiguity has been additionally analyzed through the calculation of the degree of ambiguity (i.e., determination of the stability of meaning) and the index of the degree of ambiguity (i.e., determination of the consistency of meaning).
\end{abstract}

Key words: syntactic ambiguity, degree of ambiguity, homonymy, Bosnian language 